\title{
THE ASSOCIATION OF LOW TRIIODOTHYRONINE SYNDROME, PROTEIN-ENERGY WASTING AND CHRONIC INFLAMMATION WITH MORTALITY IN PREVALENT DIALYSIS PATIENTS
}

\author{
Nataša Črne Fureš ${ }^{1}$, Marko Lucijanić Igor Žabić $^{3}$, Karmela Altabas ${ }^{1}$ and Draško Pavlović ${ }^{1}$ \\ ${ }^{1}$ Division of Nephrology and Dialysis, Department of Internal Medicine, Sestre milosrdnice \\ University Hospital Centre, Zagreb, Croatia; ${ }^{2}$ Division of Hematology, Department of Internal Medicine, \\ Dubrava University Hospital, Zagreb, Croatia; ${ }^{3}$ Division of Nephrology and Dialysis, \\ Department of Internal Medicine, Dr Tomislav Bardek General Hospital, Koprivnica, Croatia
}

\begin{abstract}
SUMMARY - This prospective study in prevalent dialysis patients investigated prognostic properties of low triiodothyronine syndrome, protein-energy wasting and chronic inflammation. Ninetyfour prevalent dialysis patients were followed-up for a median of 39 months. Demographic, anthropometric and biochemical parameters were collected at baseline. Univariate and multivariate analysis was done using Cox regression analysis. ROC curve analysis using survival status as a classification variable was performed with the goal of determining optimal cut-off values for numerical variables. In our population, low total triiodothyronine (hazard ratio (HR) 2.19, $\mathrm{p}=0.038$ ), catheter as vascular access (HR 2.76, $\mathrm{p}=0.023$ ), higher vintage (HR 1.01, $\mathrm{p}=0.014$ ) and higher Charlson comorbidity index (HR $1.28, \mathrm{p}=0.017$ ) were statistically significantly associated with inferior survival. In our group of steady-state dialysis patients, total triiodothyronine seemed to be the strongest predictor of inferior survival among thyroid hormones. Taking this parameter into account, it was possible to identify patients at an increased risk of death even after adjustment for other prognostically relevant variables. However, after further adjustment for significant risk factors, the impact of $\mathrm{C}$-reactive protein and albumin on survival disappeared due to the overlapping prognostic properties. We concluded that triiodothyronine was an independent prognostic factor in our study group.
\end{abstract}

Key words: Dialysis; Euthyroid sick syndrome; Inflammation; Risk factors; Croatia

\section{Introduction}

Patients with end-stage renal disease (ESRD) are known to have a higher risk of mortality and morbidity than the general population. Risk factors for mortality in this group of patients are unique since there is a high prevalence of elderly patients with multiple comorbidities. Also, they have survived long enough to

Correspondence to: Nataša Črne Furěs, MD, PhD, Division of Nephrology and Dialysis, Department of Internal Medicine, Sestre milosrdnice University Hospital Centre, Vinogradska c. 29, HR-10000 Zagreb, Croatia

E-mail: natasacrne@gmail.com

Received January 11, 2018, accepted March 6, 2018 develop kidney failure. There is the need to develop a special predictive model that could be applied to ESRD patients. Research has been focused on biomarkers that could be novel risk factors that increase the accuracy of prognosis in patients with ESRD ${ }^{1}$.

One of the studied mortality risk markers in patients with ESRD is triiodothyronine (T3), whether in its free (fT3) or bound form (T3). Reduction of T3 levels, while the levels of thyroid-stimulating hormone (TSH) remain in the reference range, is known as the low T3 syndrome. It is the most frequently observed thyroid hormone alteration in ESRD patients ${ }^{2-4}$. Chronic kidney disease affects both the hypothalamus-pituitary-thyroid axis and thyroid hormone pe- 
ripheral metabolism. Reduction in T3 concentrations has been linked to a decrease in peripheral synthesis of $\mathrm{T} 3$ from thyroxine $(\mathrm{T} 4)^{2}$. It has been shown in many survival studies so far that low T3 syndrome is a risk factor for mortality both in hemodialysis (HD) $)^{5-9}$ and peritoneal dialysis (PD) patients ${ }^{10,11}$.

Another novel mortality biomarkers in ESRD patients are protein-energy wasting (PEW) and chronic inflammation ${ }^{1}$. PEW is a state of decreased body stores of protein and fat masses. It can result from inadequate diet. However, in kidney disease there are some specific causes such as inflammatory processes, intercurrent catabolic illnesses, nutrient losses into dialysate, metabolic acidosis, resistance to insulin, growth hormone, and insulin-like growth factor-1, hyperglucagonemia, hyperparathyroidism, and loss of blood into the hemodialyzer, into stool or by blood drawing ${ }^{12}$. Studies in well-characterized hemodialysis populations indicate that $\mathrm{C}$-reactive protein (CRP) levels (as a marker of chronic inflammation) are a consistent predictor of survival ${ }^{1}$, whereas serum albumin is known as a negative acute phase reactant, but also as one of the markers of $\mathrm{PEW}^{13}$.

In complex processes of acute and chronic inflammation in patients with ESRD, studies have shown strong association between inflammation markers and low T3 syndrome, where $\mathrm{fT} 3 / \mathrm{T} 3$ was proven to be a significant and independent predictor of survival ${ }^{14-16}$. On the other hand, Ozen et al. showed in a large cohort of prevalent hemodialysis patients that $\mathrm{fT} 3$ was a strong predictor of mortality in crude and adjusted Cox models including albumin or high-sensitivity CRP (hsCRP); however, after further adjustment for both albumin and hsCRP, the impact of fT3 on mortality disappeared ${ }^{17}$. Another study performed by Fernández-Reyes et al. showed that low fT3 levels were not predictive of long-term mortality in a subgroup of stable HD patients, who could survive for more than 12 months $^{18}$.

Our study aimed to investigate the steady-state correlation of thyroid hormones, CRP and serum albumin (and other surrogates of PEW) with mortality in our group of dialysis patients. Furthermore, taking into account a complex mortality risk factor profile of dialysis patients ${ }^{19}$, we studied correlations of available known risk factors with mortality in our patients, alongside low T3 syndrome, PEW and chronic inflammation.

\section{Patients and Methods}

\section{Patients}

In this observational prospective cohort study, prevalent HD and PD patients treated at Sestre milosrdnice University Hospital Centre in Zagreb and Dr Tomislav Bardek General Hospital in Koprivnica, were enrolled. Baseline demographic, anthropometric and biochemical parameters were collected from April to December 2014. September 20, 2017 was considered as the end of the study. Survival was determined from the day of enrolment, with a median follow-up of 39 months. Patients were censored at transplantation or when completing the follow-up period, with no loss of follow-up in any patient. The study exclusion criteria were formerly diagnosed or present signs of hyperor hypothyroidism, as well as inflammatory illness, malignancy, use of drugs that alter thyroid function (amiodarone, propranolol, lithium) and unwillingness to participate. When we began our study, there were 105 patients, but after the baseline measurements were performed, 11 patients had to be excluded due to subclinical hypothyroidism (TSH $\geq 5 \mathrm{mIU} / \mathrm{L}$ ) and clinically unrecognized inflammatory illness (CRP $>30$ $\mathrm{mg} / \mathrm{L})$. There remained 94 patients, 50 (53.2\%) males and $44(46.8 \%)$ females, median age 64 years, interquartile range (IQR) 57.3-76. Patient characteristics are shown in Table 1 . The study protocol was approved by Ethics Committees of the Sestre milosrdnice University Hospital Centre from Zagreb and Dr Tomislav Bardek General Hospital from Koprivnica. A signed informed consent was obtained from each patient.

\section{Methods}

Hemodialysis patients were dialyzed three times weekly for four hours, through either an arteriovenous fistula or central venous catheter, using a polysulfone dialyzer $1.6-1.8 \mathrm{~m}^{2}$, bicarbonate dialysis solution with dialysate flow $500 \mathrm{~mL} / \mathrm{min}$ and blood flow rate 300 $\mathrm{mL} / \mathrm{min}$. The $\mathrm{Kt} / \mathrm{V}$ as a measure of dialysis adequacy was checked weekly and targeted above 1.2. Blood was drawn before the start of hemodialysis treatment from the inserted dialysis needle or the arterial port of dialysis circuit, before contact of blood with dialyzer and before heparin administration. Peritoneal dialysis patients were treated with four 1.5- to 2-liter exchanges four times per day using standard dialysates containing glucose and icodextrin. Using the mentioned dialysis 
Table 1. Patient demographic and anthropometric characteristics

\begin{tabular}{|c|c|}
\hline Age (years) & 64 IQR (57.3-76) \\
\hline $\begin{array}{l}\text { Gender: } \\
\text { male } \\
\text { female }\end{array}$ & $\begin{array}{l}50 / 94(53.2 \%) \\
44 / 94(46.8 \%)\end{array}$ \\
\hline $\begin{array}{l}\text { Dialysis type: } \\
\text { hemodialysis } \\
\text { peritoneal dialysis }\end{array}$ & $\begin{array}{l}89 / 94(94.7 \%) \\
5 / 94(5.3 \%)\end{array}$ \\
\hline $\begin{array}{l}\text { Type of venous access } \\
\text { (HD patients): } \\
\text { AV fistula } \\
\text { catheter }\end{array}$ & $\begin{array}{l}71 / 89(79.8 \%) \\
18 / 89(20.2 \%)\end{array}$ \\
\hline $\begin{array}{l}\text { Vintage (length of time } \\
\text { on dialysis in months) }\end{array}$ & 27 IQR (14.3-60.8) \\
\hline $\mathrm{Kt} / \mathrm{V}$ & 1.4 IQR (1.2-1.5) \\
\hline $\begin{array}{l}\text { Cause of ESRD: } \\
\text { diabetic nephropathy } \\
\text { hypertensive nephropathy } \\
\text { chronic pyelonephritis } \\
\text { polycystic disease } \\
\text { obstructive uropathy } \\
\text { post-ischemic nephropathy } \\
\text { other }\end{array}$ & $\begin{array}{l}35 / 94(37.2 \%) \\
21 / 94(22.3 \%) \\
15 / 94(16 \%) \\
9 / 94(9.6 \%) \\
4 / 94(4.3 \%) \\
3 / 94(3.2 \%) \\
7 / 94(7.4 \%)\end{array}$ \\
\hline $\begin{array}{l}\text { Smoking status: } \\
\text { non-smokers } \\
\text { previous smokers } \\
\text { active smokers }\end{array}$ & $\begin{array}{l}72 / 94(76.6 \%) \\
7 / 94(7.4 \%) \\
15 / 94(16 \%) \\
\end{array}$ \\
\hline Body height $(\mathrm{cm})$ & 165 IQR (158-173.8) \\
\hline Body weight $(\mathrm{kg})$ & 74 IQR (62-85.1) \\
\hline Body mass index $\left(\mathrm{kg} / \mathrm{m}^{2}\right)$ & 26.1 IQR (23-31.8) \\
\hline Percentage of body fat (\%) & 19 IQR (15-24.8) \\
\hline Charlson comorbidity index & $6 \mathrm{IQR}(4-7)$ \\
\hline
\end{tabular}

$\mathrm{IQR}=$ interquartile range; $\mathrm{HD}=$ hemodialysis; $\mathrm{AV}=$ arteriovenous; $\mathrm{Kt} / \mathrm{V}=$ measure of dialysis adequacy; $\mathrm{ESRD}=$ end-stage renal disease; $\mathrm{cm}=$ centimeter; $\mathrm{kg}=$ kilogram; $\mathrm{kg} / \mathrm{m}^{2}=$ kilogram per cubic meter

prescription, the total $\mathrm{Kt} / \mathrm{V}$ urea was aimed at minimum 1.7 per week.

At the beginning of the study, data on age, gender, type of dialysis, type of dialysis access, disease that caused ESRD, smoking habits and vintage (the length of time being treated with dialysis measured in months) were collected. Patients were measured for their body height $(\mathrm{cm})$, weight $(\mathrm{kg})$, body mass index (BMI, $\mathrm{kg} / \mathrm{m}^{2}$ ) and percentage of fat tissue (using a standard caliper, in millimeters; skinfold thickness was measured at the rear part of the upper arm, two centi-
Table 2. Baseline laboratory parameters

\begin{tabular}{|l|l|}
\hline RBC $(x 10 \mathrm{e} 12 / \mathrm{L})$ & $3.5 \mathrm{IQR}(3.3-3.8)$ \\
Hemoglobin $(\mathrm{g} / \mathrm{L})$ & $109 \pm 12.4$ \\
Hematocrit $(\mathrm{L} / \mathrm{L})$ & $0.33 \pm 0.04$ \\
MCV $(\mathrm{fL})$ & $94.9 \pm 5.2$ \\
WBC $(x 10 \mathrm{e} 9 / \mathrm{L})$ & $6.5 \pm 1.9$ \\
Platelets $(\mathrm{x} 10 \mathrm{e} 9 / \mathrm{L})$ & $176 \mathrm{IQR}(138.3-208.5)$ \\
Uric acid $(\mu \mathrm{mol} / \mathrm{L})$ & $327.2 \mathrm{IQR}(296-370)$ \\
Creatinine $(\mu \mathrm{mol} / \mathrm{L})$ & $662.1 \pm 196.7$ \\
Total cholesterol $(\mathrm{mmol} / \mathrm{L})$ & $4.1 \pm 0.8$ \\
HDL cholesterol $(\mathrm{mmol} / \mathrm{L})$ & $1.12 \mathrm{IQR}(0.9-1.4)$ \\
LDL cholesterol $(\mathrm{mmol} / \mathrm{L})$ & $2.5 \mathrm{IQR}(2.1-2.9)$ \\
Triglycerides $(\mathrm{mmol} / \mathrm{L})$ & $1.4 \mathrm{IQR}(0.9-2)$ \\
Calcium $(\mathrm{mmol} / \mathrm{L})$ & $2.2 \pm 0.2$ \\
Phosphates $(\mathrm{mmol} / \mathrm{L})$ & $1.5 \mathrm{IQR}(1.1-1.8)$ \\
Serum iron $(\mu \mathrm{mol} / \mathrm{L})$ & $12 \mathrm{IQR}(9.7-15.2)$ \\
UIBC $(\mu \mathrm{mol} / \mathrm{L})$ & $24.8 \pm 9$ \\
TIBC $(\mu \mathrm{mol} / \mathrm{L})$ & $36.4 \mathrm{IQR}(32.8-41.3)$ \\
Transferrin saturation $(\%)$ & $32 \mathrm{IQR}(25.5-43.6)$ \\
Total protein $(\mathrm{g} / \mathrm{L})$ & $65.3 \pm 5.5$ \\
Albumin $(\mathrm{g} / \mathrm{L})$ & $38.3 \pm 3.5$ \\
CRP $(\mathrm{mg} / \mathrm{L})$ & $5.7 \mathrm{IQR}(2-10.6)$ \\
Ferritin $(\mathrm{ng} / \mathrm{mL})$ & $631.4 \mathrm{IQR}(291-746.8)$ \\
PTH $(\mathrm{pg} / \mathrm{mL})$ & $249 \mathrm{IQR}(131.3-425)$ \\
Total T3 $(\mathrm{nmol} / \mathrm{L})$ & $1.1 \mathrm{IQR}(1-1.3)$ \\
fT3 $(\mathrm{pmol} / \mathrm{L})$ & $2.3 \mathrm{IQR}(2.1-2.5)$ \\
Total T4 $(\mathrm{nmol} / \mathrm{L})$ & $64.1 \mathrm{IQR}(55.5-74.1)$ \\
fT4 $(\mathrm{pmol} / \mathrm{L})$ & $12 \pm 1.7$ \\
TSH $(\mathrm{mIU} / \mathrm{L})$ & $1.5 \pm 0.7$ \\
\hline &
\end{tabular}

$\mathrm{IQR}=$ interquartile range; $\mathrm{RBC}=$ red blood count $\mathrm{MCV}=$ mean corpuscular volume; $\mathrm{WBC}=$ white blood cell count; $\mathrm{HDL}=$ highdensity lipoprotein; LDL = low-density lipoprotein; $\mathrm{UIBC}=$ unsaturated iron binding capacity; TIBC = total iron binding capacity; $\mathrm{CRP}=\mathrm{C}$-reactive protein; $\mathrm{PTH}=$ parathyroid hormone; $\mathrm{T} 3=$ triiodothyronine; $\mathrm{fT} 3$ = free triiodothyronine; $\mathrm{T} 4$ = thyroxine; $\mathrm{fT} 4=$ free thyroxine; $\mathrm{TSH}=$ thyroid-stimulating hormone

meters laterally of the umbilicus and at the front part of the thigh; it was measured at the beginning of dialysis treatment, on the second dialysis in the week). Comorbidity was evaluated using modified Charlson comorbidity index (a method of predicting mortality by classifying or weighting comorbidities), without patient age included, as it was considered separately.

Laboratory data obtained at the beginning of the second weekly hemodialysis session and the regular monthly check-up were considered baseline values in 
PD patients (Table 2). Plasma analyses of thyroid hormones and TSH were performed using Abbott commercially available Abbott assays (Abbott Laboratories, Zagreb, Croatia). All other biochemical analyses were performed on an Olympus AU2700 analyzer using original Beckman Coulter assays (Beckman Coulter, Zagreb, Croatia).

\section{Statistical analysis}

The normality of distribution of numerical variables was tested using the Kolmogorov-Smirnov test. Normally distributed numerical variables were expressed as arithmetic mean \pm standard deviation (SD), and were compared between the groups using the Ttest. Non-normally distributed numerical variables were expressed as median and IQR, and were compared between the groups using the Mann Whitney $U$ test. Correlation between numerical variables was assessed using Pearson or Spearman correlation depending on their normality of distribution. Categorical variables were expressed as number and proportion, and were compared between the groups using the $\chi^{2}$ test or Fisher exact test when appropriate. Survival analyses were based on the Kaplan-Meier method. Univariate and multivariate analysis of factors associated with survival of patients was performed using the Cox regression analysis. ROC curve analysis using survival status as a classification variable was performed to determine optimal cut-off values for numerical variables. The level of statistical significance was set at $\mathrm{p}<0.05$. All analyses were performed using the MedCalc Statistical software, version 17.8.1 (MedCalc Software bvba, Ostend, Belgium).

\section{Results}

\section{Thyroid hormones and TSH and their clinical and laboratory correlations}

The mean TSH value was $1.5 \pm 0.7 \mathrm{mIU} / \mathrm{L}$. Higher TSH was statistically significantly associated with lower uric acid (Rho -0.22, p=0.033), lower unsaturated iron binding capacity (UIBC) (Rho -0.25 , $\mathrm{p}=0.014)$ and higher transferrin saturation (Rho 0.22, $\mathrm{p}=0.033$ ). In our cohort of patients with normal TSH values, there was no statistically significant association of TSH with other thyroid hormones.
The median total T3 value was $1.1 \mathrm{nmol} / \mathrm{L}, \mathrm{IQR}$ (1-1.3). Higher total T3 was statistically significantly associated with younger age (Rho $-0.25, \mathrm{p}=0.017$ ), higher body weight (Rho 0.2, $\mathrm{p}=0.049$ ), higher red blood cell count (RBC) (Rho 0.24, p=0.021), lower mean corpuscular volume (MCV) (Rho -0.26, $\mathrm{p}=0.010$ ), higher albumin (Rho 0.27, $\mathrm{p}=0.008$ ), lower ferritin (Rho -0.22, $\mathrm{p}=0.031$ ), higher fT3 (Rho 0.35, $\mathrm{p}=0.001$ ) and higher total T4 (Rho 0.34, $\mathrm{p}=0.001$ ).

The median fT3 value was $2.3 \mathrm{pmol} / \mathrm{L}$, IQR (2.12.5). Higher fT3 was statistically significantly associated with peritoneal dialysis (median 4.36 vs. 2.23, $\mathrm{p}<0.001)$, younger age (Rho $-0.24, \mathrm{p}=0.020)$, lower Charlson comorbidity index (Rho $-0.35, \mathrm{p}=0.001$ ), higher body height (Rho 0.34, $\mathrm{p}=0.001$ ), higher body weight (Rho 0.33, $\mathrm{p}=0.001$ ), higher uric acid (Rho 0.27, $\mathrm{p}=0.010$ ), higher UIBC (Rho 0.36, $\mathrm{p}<0.001$ ), higher total iron binding capacity (TIBC) (Rho 0.41, $\mathrm{p}<0.001$ ), lower transferrin saturation (Rho -0.21 , $\mathrm{p}=0.044$ ), higher albumin (Rho 0.25, $\mathrm{p}=0.014$ ), higher total T3 (Rho 0.35, $\mathrm{p}=0.001$ ), higher total T4 (Rho 0.36, $\mathrm{p}<0.001$ ) and higher fT4 (Rho 0.41, $\mathrm{p}<0.001$ ).

The median total T4 value was $64.1 \mathrm{nmol} / \mathrm{L}$, IQR (55.5-74.1). Higher total T4 was statistically significantly associated with peritoneal dialysis (median 88.8 vs. 62.6, $\mathrm{p}=0.001$ ), higher Kt/V (Rho 0.29, $\mathrm{p}=0.005$ ), lower serum iron (Rho $-0.25, \mathrm{p}=0.017$ ), higher UIBC (Rho 0.31, $\mathrm{p}=0.003$ ), higher TIBC (Rho 0.21, $\mathrm{p}=0.039$ ), lower transferrin saturation (Rho $-0.31, \mathrm{p}=0.003$ ), lower parathyroid hormone (PTH) (Rho -0.22, $\mathrm{p}=0.038$ ), higher total T3 (Rho 0.34, $\mathrm{p}=0.001$ ), higher fT3 (Rho 0.36, p<0.001) and higher fT4 (Rho 0.86, $\mathrm{p}<0.001)$.

The mean fT4 value was $12 \pm 1.7 \mathrm{pmol} / \mathrm{L}$. Higher fT4 was statistically significantly associated with peritoneal dialysis (median 14.4 vs. 11.72, $\mathrm{p}=0.003$ ), higher Kt/V (Rho 0.25, p=0.015), lower serum iron ( $R$ ho -0.21, $\mathrm{p}=0.042$ ), higher UIBC (Rho 0.26, $\mathrm{p}=0.011$ ), lower transferrin saturation (Rho $-0.28, \mathrm{p}=0.006$ ), lower PTH (Rho -0.25, p=0.014), higher fT3 (Rho $0.41, \mathrm{p}<0.001$ ) and higher total T4 (Rho 0.86, $\mathrm{p}<0.001)$.

\section{Survival of patients}

The median follow up of our patients was 39 months. Forty-two patients died during the follow up period. The most common causes of death were sudden cardiac death in $17 / 94$ (40.5\%), sepsis in $17 / 94$ 
A

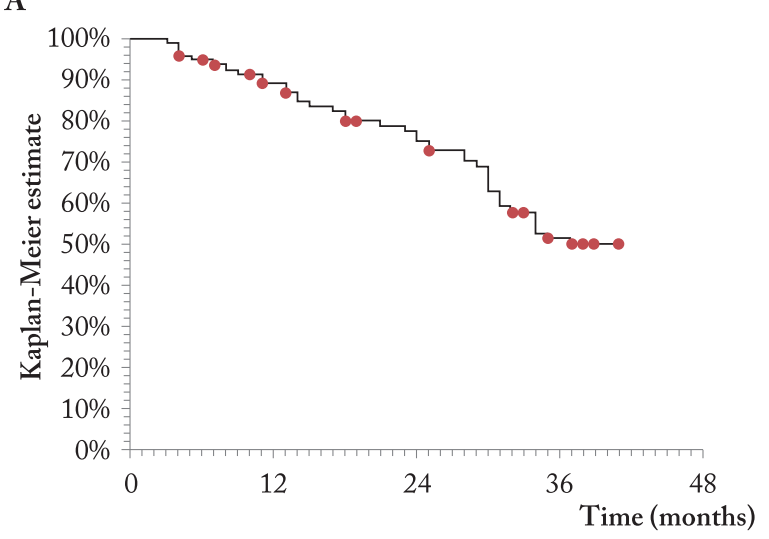

B

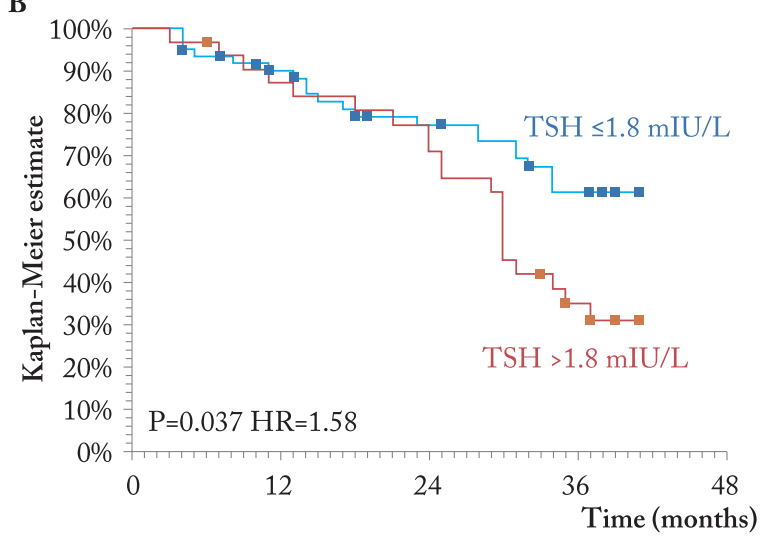

D

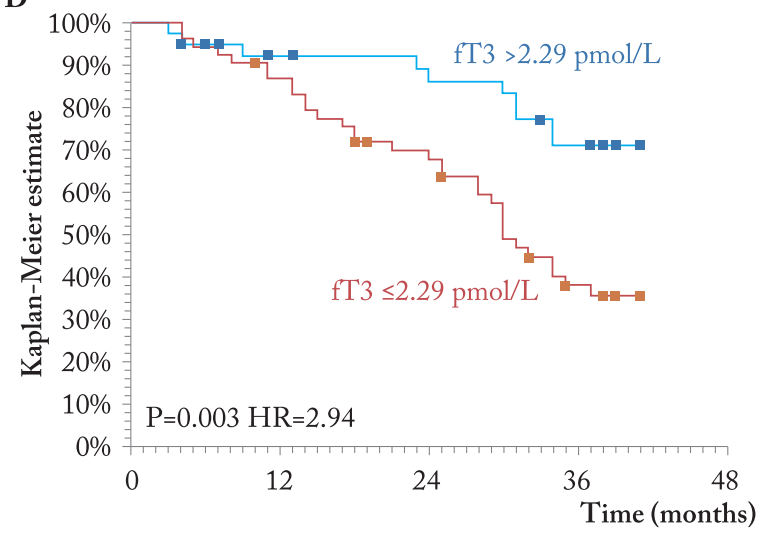

F

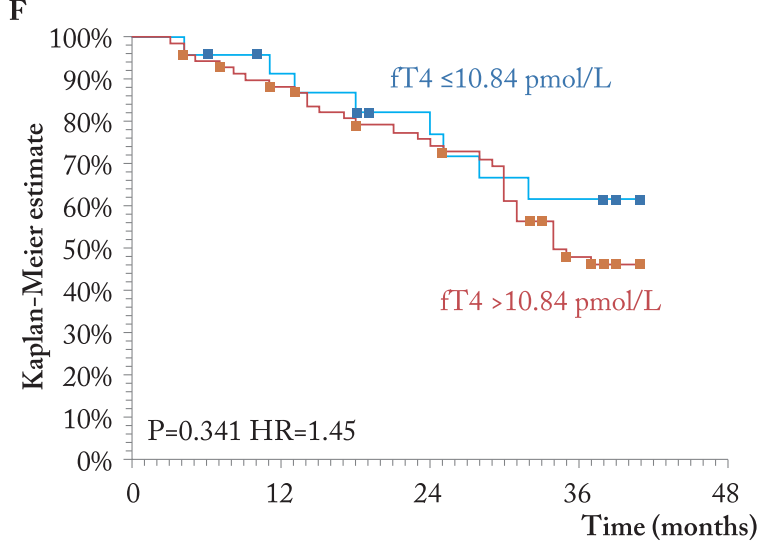

Fig. 1. (A) Survival curve for all patients; (B) higher TSH; (C) lower total T3; and (D) lower fT3 were associated with inferior survival; $(E)$ total T4; and $(F) f T 4$ were not significantly associated with survival.

*statistically significant at $\mathrm{p}<0.05 ; \mathrm{TSH}=$ thyroid-stimulating hormone; $\mathrm{T} 3$ = triiodothyronine; $\mathrm{fT} 3$ = free triiodothyronine; $\mathrm{T} 4$ = thyroxine; $\mathrm{fT} 4$ = free thyroxine; $\mathrm{HR}=$ hazard ratio

(40.5\%), disseminated malignant disease in $2 / 42$ (4.8\%), cerebrovascular insult in $2 / 42(4.8 \%)$ patients, and hepatocellular carcinoma, myocardial infarction, suspected pulmonary embolism and unknown cause of death in one patient each. Survival curve for all pa- tients is shown in Figure 1A. Median survival was not reached; the 3-year survival rate was 51.4\%.

Optimal cut-off values with best survival discriminatory properties for thyroid hormones were determined using ROC curve analysis. The cut-off for TSH 
Table 3. Cox regression analysis investigating associations of thyroid hormones with survival

\begin{tabular}{|l|l|l|}
\hline Variable & HR; 95\% CI & $\mathrm{p}$ \\
\hline Total T3 <1 nmol/L & $\begin{array}{l}\text { HR 2.26 } \\
\text { 95\% CI [1.15-4.44] }\end{array}$ & $0.019^{*}$ \\
$\mathrm{fT} 3 \leq 2.29 \mathrm{pmol} / \mathrm{L}$ & $\begin{array}{l}\text { HR 2.83 } \\
\text { 95\% CI [1.36-5.88] }\end{array}$ & $0.005^{*}$ \\
$\mathrm{TSH}>1.8 \mathrm{mIU} / \mathrm{L}$ & $\begin{array}{l}\text { HR 2.03 } \\
\text { 95\% CI [1.06-3.9] } \\
\text { HR 1.56 } \\
\text { 95\% CI [0.77-3.19] } \\
\text { Total T4 } \leq 68 \mathrm{nmol} / \mathrm{L} 1.79\end{array}$ & $0.033^{*}$ \\
$\mathrm{fT} 4>10.84 \mathrm{pmol} / \mathrm{L}$ & $\begin{array}{l}\text { HR } \\
\text { 95\% CI }[0.76-4.22]\end{array}$ & 0.181 \\
\hline
\end{tabular}

*statistically significant at $\mathrm{p}<0.05 ; 95 \% \mathrm{CI}=95 \%$ confidence interval; $\mathrm{HR}=$ hazard ratio; $\mathrm{T} 3$ = triiodothyronine; $\mathrm{fT} 3$ = free triiodothyronine; $\mathrm{TSH}=$ thyroid-stimulating hormone; $\mathrm{T} 4$ = thyroxine; $\mathrm{fT} 4=$ free thyroxine

was set at $>1.8 \mathrm{mIU} / \mathrm{L}$. Although all patients had TSH values within the reference range, patients with higher TSH values experienced shorter survival in comparison to those with lower TSH values at baseline, as shown in Figure 1B (hazard ratio (HR) 1.58, $\mathrm{p}=0.037$ ). Both groups experienced similar survival for the period of 2 years, then survival curves started to diverge. The cut-off for total T3 was set at $<1 \mathrm{nmol} / \mathrm{L}$; patients with lower total T3 levels had inferior survival in comparison to patients with higher (normal) total T3 levels, as shown in Figure 1C (HR 1.97, p=0.038). The cut-off for $\mathrm{fT} 3$ was set at $>2.29 \mathrm{pmol} / \mathrm{L}$; patients with lower fT3 similarly had inferior survival in comparison to patients with higher (normal) fT3 values, as shown in Figure 1D (HR 2.94, p=0.003). The cut-off values obtained for total T4 and fT4 were $<86 \mathrm{nmol} / \mathrm{L}$ and $>10.84 \mathrm{pmol} / \mathrm{L}$, respectively. Total T4 $(\mathrm{p}=0.158)$ and $\mathrm{fT} 4(\mathrm{p}=0.341)$ were not statistically significantly associated with survival in our cohort of patients.

We compared prognostic properties of different thyroid hormones in a Cox regression model containing TSH, total T3, fT3, total T4 and $\mathrm{fT} 4$, as shown in Table 3. Low total T3 (HR 2.26, p=0.019), low fT3 (HR 2.83, p=0.005) and high-normal TSH (HR 2.03, $\mathrm{p}=0.033$ ) each bore an independent prognostic potential as they were able to retain statistical significance and predict survival independently of each other.

Other parameters that were univariately associated with survival were catheter as venous access (HR 2.44, $\mathrm{p}=0.008)$, age (HR 1.05, $\mathrm{p}=0.001)$, vintage (HR 1.01,
Table 4. Cox regression model investigating associations of total T3, fT3, TSH and other univariately significant variables with survival

\begin{tabular}{|c|c|c|}
\hline Variable & HR; 95\% CI & $\mathrm{p}$ \\
\hline Total T3 < $1 \mathrm{nmol} / \mathrm{L}$ & $\begin{array}{l}\text { HR } 2.19 \\
95 \% \text { CI (1.05-4.6) }\end{array}$ & $0.038^{*}$ \\
\hline $\mathrm{fT} 3 \leq 2.29 \mathrm{pmol} / \mathrm{L}$ & $\begin{array}{l}\text { HR } 1.61 \\
95 \% \text { CI (0.68-3.83) }\end{array}$ & 0.283 \\
\hline TSH >1.8 mIU/L & $\begin{array}{l}\text { HR } 1.67 \\
95 \% \text { CI (0.86-3.24) }\end{array}$ & 0.128 \\
\hline $\begin{array}{l}\text { Catheter as venous } \\
\text { access }\end{array}$ & $\begin{array}{l}\text { HR } 2.76 \\
95 \% \text { CI (1.15-6.62) }\end{array}$ & $0.023^{*}$ \\
\hline Age (years) & $\begin{array}{l}\text { HR } 1.03 \\
95 \% \text { CI (0.99-1.06) }\end{array}$ & 0.122 \\
\hline Male gender & $\begin{array}{l}\text { HR } 1.39 \\
95 \% \text { CI (0.65-2.98) }\end{array}$ & 0.398 \\
\hline Vintage (months) & $\begin{array}{l}\text { HR } 1.01 \\
95 \% \text { CI (1-1.02) }\end{array}$ & $0.014^{*}$ \\
\hline $\begin{array}{l}\text { Charlson comorbidity } \\
\text { index }\end{array}$ & $\begin{array}{l}\text { HR } 1.28 \\
95 \% \text { CI (1.05-1.57) }\end{array}$ & $0.017^{*}$ \\
\hline Body height (cm) & $\begin{array}{l}\text { HR } 1 \\
95 \% \text { CI (0.97-1.03) }\end{array}$ & 0.996 \\
\hline Albumin (g/L) & $\begin{array}{l}\text { HR } 0.94 \\
95 \% \text { CI (.82-1.08) }\end{array}$ & 0.383 \\
\hline $\mathrm{CRP}(\mathrm{mg} / \mathrm{L})$ & $\begin{array}{l}\text { HR } 1.01 \\
95 \% \text { CI (0.97-1.05) }\end{array}$ & 0.624 \\
\hline
\end{tabular}

*statistically significant at $\mathrm{p}<0.05 ; 95 \% \mathrm{CI}=95 \%$ confidence interval; $\mathrm{HR}=$ hazard ratio; $\mathrm{T} 3$ = triiodothyronine; $\mathrm{fT} 3=$ free triiodothyronine; $\mathrm{TSH}=$ thyroid-stimulating hormone; $\mathrm{CRP}=\mathrm{C}$-reactive protein

$\mathrm{p}=0.034)$, Charlson comorbidity index (HR 1.39, $\mathrm{p}<0.001$ ), body height (HR 0.07, $\mathrm{p}=0.021$ ), albumin (HR 0.88, p=0.008) and CRP (HR 1.04, p=0.006). We further investigated prognostic properties of thyroid hormones in a Cox regression analysis model including total T3, fT3, TSH and other factors mentioned above that were univariately associated with survival and gender, as shown in Table 4. Low total T3 (HR 2.19, $\mathrm{p}=0.038$ ), catheter as venous access (HR 2.76, $\mathrm{p}=0.023$ ), higher vintage (HR 1.01, $\mathrm{p}=0.014)$ and higher Charlson comorbidity index (HR 1.28, $\mathrm{p}=0.017)$ remained statistically significantly associated with inferior survival.

\section{Discussion}

Study results showed that in our group of steadystate dialysis patients, total T3 seemed to be an inde- 
pendent predictor of inferior survival among thyroid hormones. It could identify patients at an increased risk of death even after adjustment for other prognostically relevant variables. It was interesting to see that the higher values of TSH, when using only thyroid hormones in the analysis, were a significant mortality risk, even though all the TSH values were in the reference range since we were focusing exclusively on the low T3 syndrome. However, when we included other statistically relevant confounding factors, TSH values lost their significance.

The results from earlier studies showed that serum albumin and CRP were significantly related with allcause mortality ${ }^{13}$ and that the CRP levels were a consistent predictor of survival in hemodialysis populations ${ }^{1}$. However, in our study, after further adjustment for fT3, T3, TSH and other significant confounding factors, the impact of CRP and albumin on survival disappeared due to overlapping prognostic properties. We concluded that, although it is known that low T3 syndrome and PEW are interrelated ${ }^{15,16}$, in our group of patients T3 had greater influence on survival.

It has been recognized that all-cause and cardiovascular mortality is consistently higher in long-term dialysis patients with derangements in thyroid function test results. It is a question whether it would be cost-effective to screen for thyroid function among patients with $\mathrm{ESRD}^{20}$. When validating a potential new prognostic biomarker, there are four criteria to consider. The first one is accuracy, which is the ability to reliably identify individuals at a greater risk of the adverse clinical outcome of interest. The second one is simplicity (for example, ease of measurement). The third one is the cost (biomarkers should be inexpensive and cost-effective), and the last one is the relevance of the information provided by the biomarker ${ }^{21}$. According to the results of our study, and to the available scientific information gathered so far, it is our opinion that T3 should be considered as an important novel prognostic factor that should be taken into consideration when analyzing survival chances of patients on dialysis.

Furthermore, in our study, using a central venous catheter (CVC) as vascular access in hemodialysis patients proved to be a significant mortality risk factor. This finding is in accordance with the results of another study comparing different types of vascular access (CVC, arteriovenous fistulas (AVF) and arterio- venous grafts $(\mathrm{AVG}))^{22}$. In this study, the survival rate among patients in whom hemodialysis was initiated with AVF was significantly higher than that in patients in whom hemodialysis was initiated with AVG or $\mathrm{CVC}^{22}$. Patients who started hemodialysis and were using a venous catheter were at a $47 \%$ higher death risk compared with patients who were using an AVF. This association remained unaltered after adjustment for the potential confounding factors and after accounting for frequent changes in access type over time $^{23}$. What is interesting about our finding is that, to the best of our knowledge, there has not been a study that investigated the correlation of thyroid hormones with mortality in dialysis patients, alongside other mortality risk factors, which also included the hemodialysis access. For this reason, we would suggest that hemodialysis vascular access be taken into account as an essential risk factor in the future survival studies.

The results of our study confirmed once more that Charlson comorbidity index is a valid tool for assessing comorbidity burden in dialysis patients ${ }^{24-26}$. Also, following previous studies ${ }^{27}$, the dialysis vintage is a significant mortality risk.

Risk prediction models can be used to inform the patients undergoing renal replacement therapy about their survival chances. Hemke et al. showed that a simple model based only on registry data could be enhanced by adding readily available clinical parameters, such as cholesterol, phosphate, and albumin ${ }^{28}$. The associations among the main risk factors for death in hemodialysis patients are complex. A study by Kanda et al. showed that simultaneous evaluation of multiple risk factors could accurately assess patient prognosis and identify patients at an increased risk of death ${ }^{19}$. Based on the results of our study, we agree with the conclusions of the studies above regarding the necessity of multiple mortality risk factor approach in assessing prognosis of ESRD patients.

Our study had some limitations. The cohort had less than 100 patients, and the median follow up of our patients was 39 months. The question remains whether the parameters that were statistically significant would remain significant if the study group was larger and the follow up longer. Furthermore, we did not consider blood pressure as a confounder. It was proven that lower blood pressure in patients on hemodialysis (predialysis systolic $<110 \mathrm{~mm} \mathrm{Hg}$ ), as well as higher blood pressure (predialysis systolic $150-159 \mathrm{~mm} \mathrm{Hg}$ ) was as- 
sociated with higher mortality ${ }^{29}$. Finally, it is a question whether measures that we included in the study, such as serum albumin, BMI and percentage of fat tissue, were adequate to assess completely the presence of $\mathrm{PEW}$. We were unable to assess dietary protein intake or dietary energy intake, which are considered as components of this syndrome ${ }^{12}$.

In conclusion, T3 seems to be the most reliable predictor of inferior survival among thyroid hormones. It could identify patients at an increased risk of death even after adjustment for other prognostically relevant variables, and it should be considered as an important mortality risk factor in evaluating the prognosis of ESRD patients.

\section{Acknowledgments}

The authors wish to express their appreciation to the whole dialysis nursing staff at the Sestre milosrdnice University Hospital Centre from Zagreb (Marica Prša, Head Nurse) and Dr Tomislav Bardek General Hospital from Koprivnica (Dražen Buhanec, Head Medical Technician) (clinical studies), as well as to Ivana Ćelap, MSc, and Professor Nada Vrkić, PhD (biochemical analysis).

\section{References}

1. Ortiz A, Massy ZA, Fliser D, Lindholm B, Wiecek A, Martínez-Castelao A, Covic A, Goldsmith D, Süleymanlar G, London GM, Zoccali C. Clinical usefulness of novel prognostic biomarkers in patients on hemodialysis. Nat Rev Nephrol. 2011 Nov 1;8(3):141-50. DOI: 10.1038/nrneph.2011.170

2. Kaptein EM. Thyroid hormone metabolism and thyroid diseases in chronic renal failure. Endocr Rev. 1996 Feb;17(1): 45-63. DOI: $10.1210 /$ edrv-17-1-45

3. Lim VS, Fang VS, Katz AI, Refetoff S. Thyroid dysfunction in chronic renal failure. A study of pituitary-thyroid axis and peripheral turnover kinetics of thyroxine and triiodothyronine. J Clin Invest. 1977 Sep;60(3):522-34.DOI: 10.1172/JCI108804

4. Lo JC, Chertow GM, Go AS, Hsu CY. Increased prevalence of subclinical and clinical hypothyroidism in persons with chronic kidney disease. Kidney Int. 2005 Mar;67(3):1047-52. DOI: 10.1111/j.1523-1755.2005.00169.x

5. Carrero JJ, Qureshi AR, Axelsson J, Yilmaz MI, Rehnmark S, Witt MR, Bárány P, Heimbürger O, Suliman ME, Alvestrand A, Lindholm B, Stenvinkel P. Clinical and biochemical implications of low thyroid hormone levels (total and free forms) in euthyroid patients with chronic kidney disease. J Intern Med. 2007 Dec;262(6):690-701.

DOI: $10.1111 / \mathrm{j} .1365-2796.2007 .01865 . x$
6. Zoccali C, Mallamaci F, Tripepi G, Cutrupi S, Pizzini P. Low triiodothyronine and survival in end-stage renal disease. Kidney Int. 2006 Aug;70(3):523-8. DOI: 10.1038/sj.ki.5001566

7. Horáček J, Dusilová Sulková S, Kubišová M, Šafránek R, Malířová E, Kalousová M, Svilias I, Maly J, Sobotka L, Žák P. Thyroid hormone abnormalities in hemodialyzed patients: low triiodothyronine as well as high reverse triiodothyronine are associated with increased mortality. Physiol Res. 2012;61(5): 495-501.

8. Drechsler C, Schneider A, Gutjahr-Lengsfeld L, Kroiss M, Carrero JJ, Krane V, Allolio B, Wanner C, Fassnacht M. Thyroid function, cardiovascular events, and mortality in diabetic hemodialysis patients. Am J Kidney Dis. 2014;63(6):988-96. DOI: $10.1053 /$ j.ajkd.2013.10.009

9. Meuwese CL, Dekker FW, Lindholm B, Qureshi AR, Heimburger O, Barany P, Stenvinkel P, Carrero JJ. Baseline levels and trimestral variation of triiodothyronine and thyroxine and their association with mortality in maintenance hemodialysis patients. Clin J Am Soc Nephrol. 2012 Jan;7(1):131-8. DOI: 10.2215/CJN.05250511

10. Chang TI, Nam JY, Shin SK, Kang EW. Low triiodothyronine syndrome and long-term cardiovascular outcome in incident peritoneal dialysis patients. Clin J Am Soc Nephrol. 2015 Jun;10(6):975-82. DOI: 10.2215/CJN.03350414

11. Meuwese CL, Carrero JJ, Cabezas-Rodríguez I, Heimburger O, Barany P, Lindholm B, Qureshi AR, Ripsweden J, Dekker FW, Stenvinkel P. Nonthyroidal illness: a risk factor for coronary calcification and arterial stiffness in patients undergoing peritoneal dialysis? J Intern Med. 2013 Dec;274(6):584-93. DOI: $10.1111 /$ joim. 12107

12. Fouque D, Kalantar-Zadeh K, Kopple J, Cano N, Chauveau P, Cuppari L, Franch H, Guarnieri G, Ikizler TA, Kaysen G, Lindholm b, Massy Z, Mitch W, Pineda E, Stenvinkel P, Trevinho-Becerra A, Wanner C. A proposed nomenclature and diagnostic criteria for protein-energy wasting in acute and chronic kidney disease. Kidney Int. 2008 Aug;74(3):391-8. DOI: $10.1038 /$ sj.ki.5002585

13. Herselman M, Esau N, Kruger JM, Labadarios D, Moosa MR. Relationship between serum protein and mortality in adults on long-term hemodialysis: exhaustive review and meta-analysis. Nutrition. 2010 Jan;26(1):10-32. DOI: $10.1016 /$ j.nut.2009.07.009

14. Zoccali C, Tripepi G, Cutrupi S, Pizzini P, Mallamaci F. Low triiodothyronine: a new facet of inflammation in end-stage renal disease. J Am Soc Nephrol. 2005 Sep;16(9):2789-95. DOI: 10.1681/ASN.2005040356

15. Enia G, Panuccio V, Cutrupi S, Pizzini P, Tripepi G, Mallamaci F, Zoccali C. Subclinical hypothyroidism is linked to micro-inflammation and predicts death in continuous ambulatory peritoneal dialysis. Nephrol Dial Transplant. 2007 Feb;22(2): 538-44. DOI: $10.1093 / \mathrm{ndt} / \mathrm{gf6} 65$

16. Koo HM, Kim CH, Doh FM, Lee MJ, Kim EJ, Han JH, Han JS, Oh HJ, Han SH, Yoo TH, Kang SW. The impact of low triiodothyronine levels on mortality is mediated by malnutri- 
tion and cardiac dysfunction in incident hemodialysis patients. Eur J Endocrinol. 2013 Sep 12;169(4):409-19. DOI: 10.1530/ EJE-13-0540

17. Ozen KP, Asci G, Gungor O, Carrero JJ, Kircelli F, Tatar E, Ok ES, Ozkahya M, Toz H, Cirit M, Basci A, Ok E. Nutritional state alters the association between free triiodothyronine levels and mortality in hemodialysis patients. Am J Nephrol. 2011; 33(4):305-12. DOI: $10.1159 / 000324883$

18. Fernández-Reyes MJ, Diez JJ, Collado A, Iglesias P, Bajo MA, Estrada P, del Peso G, Heras M, Molina A, Selgas R. Are low concentrations of serum triiodothyronine a good marker for long-term mortality in hemodialysis patients? Clin Nephrol. 2010 Mar;73(3):238-40.

19. Kanda E, Bieber BA, Pisoni RL, Robinson BM, Fuller DS. Importance of simultaneous evaluation of multiple risk factors for hemodialysis patients' mortality and development of a novel index: dialysis outcomes and practice patterns study. PloS One. 2015 Jun 1;10(6):e0128652.

DOI: 10.1371 /journal.pone.0128652

20. Xu H, Brusselaers N, Lindholm B, Zoccali C, Carrero JJ. Thyroid function test derangements and mortality in dialysis patients: a systematic review and meta-analysis. Am J Kidney Dis. 2016;68(6):923-32. DOI: 10.1053/j.ajkd.2016.06.023

21. Manolio T. Novel risk markers and clinical practice. N Engl J Med. 2003 Oct 23;349(17):1587-9. DOI: $10.1056 /$ NEJMp038136

22. Ozeki T, Shimizu H, Fujita Y, Inaguma D, Maruyama S, Ohyama Y, Minatoguchi S, Murai Y, Terashita M, Tagaya T. The type of vascular access and the incidence of mortality in Japanese dialysis patients. Intern Med. 2017;56(5):481-5. DOI: 10.2169/internalmedicine.56.7563
23. Astor BC, Eustace JA, Powe NR, Klag MJ, Fink NE, Coresh J. Type of vascular access and survival among incident hemodialysis patients: the Choices for Healthy Outcomes in Caring for ESRD (CHOICE) Study. J Am Soc Nephrol. 2005 May;16(5):1449-55. DOI: 10.1681/ASN.2004090748

24. Fried L, Bernardini J, Piraino B. Charlson comorbidity index as a predictor of outcomes in incident peritoneal dialysis patients. Am J Kidney Dis. 2001 Feb;37(2):337-42. DOI: 10.1053/ ajkd.2001.21300

25. Charlson ME, Pompei P, Ales KL, MacKenzie CR. A new method of classifying prognostic comorbidity in longitudinal studies: development and validation. J Chronic Dis. 1987;40 (5):373-83.

26. van Manen JG, Korevaar JC, Dekker FW, Boeschoten EW, Bossuyt PMM, Krediet RT. For the NECOSAD Study group. How to adjust for comorbidity in survival studies in ESRD patients: a comparison of different indices. Am J Kidney Dis. 2002 Jul;40(1):82-9. DOI: 10.1053/ajkd.2002.33916

27. Chertow GM, Johansen KL, Lew N, Lazarus JM, Lowrie EG. Vintage, nutritional status, and survival in hemodialysis patients. Kidney Int. 2000 Mar;57(3):1176-81. DOI: $10.1046 / \mathrm{j} .1523-1755.2000 .00945 . x$

28. Hemke AC, Heemskerk MB, van Diepen M, Dekker FW, Hoitsma AJ. Improved mortality prediction in dialysis patients using specific clinical and laboratory data. Am J Nephrol. 2015;42(2):158-67. DOI: $10.1159 / 000439181$

29. Port FK, Hulbert-Shearon TE, Wolfe RA, Bloembergen WE, Golper TA, Agodoa LY, Young EW. Predialysis blood pressure and mortality risk in a national sample of maintenance hemodialysis patients. Am J Kidney Dis. 1999 Mar;33(3):507-17.

Sažetak

\section{POVEZANOST SINDROMA NISKOG TRIJODTIRONINA, PROTEINSKO ENERGETSKE POTHRANJENOSTI I KRONIČNE UPALE SA SMRTNOŠĆU PREVALENTNIH DIJALIZNIH BOLESNIKA}

\section{N. Črne Fureš, M. Lucijanić, I. Žabić, K. Altabas i D. Pavlović}

Cilj je bio istražiti prognostička svojstva sindroma niskog trijodtironina, proteinsko energetske pothranjenosti i kronične upale te drugih poznatih rizičnih čimbenika sa smrtnošću prevalentnih dijaliznih bolesnika. Ukupno 94 prevalentnih dijaliznih bolesnika prospektivno je praćeno kroz medijan od 39 mjeseci. Na početku istraživanja sakupljeni su demografski, antropometrijski i biokemijski parametri. Učinjena je univarijatna te multivarijatna analiza primjenom Coxove regresijske analize. Kako bismo odredili optimalne granične vrijednosti numeričkih varijabla primijenjena je ROC analiza krivulje koristeći preživljenje kao klasifikacijsku varijablu. $U$ našoj populaciji bolesnika su nizak ukupni trijodtironin (hazard ratio (HR) 2,19; $\mathrm{p}=0,038)$, kateter kao vaskularni pristup (HR 2,76; $\mathrm{p}=0,023)$, duži vintage (HR 1,01; $\mathrm{p}=0,014)$ i viši Charlson indeks komorbiditeta (HR 1,28; p=0,017) bili statistički značajno povezani s lošijim preživljenjem. U našoj skupini stabilnih dijaliznih bolesnika ukupni trijodtironin je među hormonima štitnjače bio najjači predskazatelj lošijeg preživljenja. Također, i nakon prilagodbe za druge prognostički značajne varijable vrijednost trijodtironina se i dalje može koristiti u prognozi bolesnika na dijalizi. Nakon daljnje analize prilagođene za druge značajne čimbenike rizika utjecaj C-reaktivnog proteina i albumina na smrtnost je nestao zbog prognostičkih svojstava koja se podudaraju. Zaključno, smatramo da je ukupni trijodtironin bio neovisan prognostički čimbenik u našoj skupini bolesnika.

Ključne riječi: Dijaliza; Netireoidna bolest štitnjače; Upala; Rizični čimbenici; Hrvatska 